\title{
Reviewable Unit Type Code
}

National Cancer Institute

\section{Source}

National Cancer Institute. Reviewable Unit Type Code. NCI Thesaurus. Code C94070.

A coded value specifying the kind of reviewable unit. 